\title{
AN ESTIMATE OF THE EFFECT OF COMMON CURRENCIES ON TRADE AND INCOME*
}

\author{
Jeffrey Frankel and Andrew Rose
}

Draft: February 11, $2002+$ minor revisions Feb. 11, 2002

Jeffrey A. Frankel

Kennedy School of Government

Harvard University, 79 JFK Street

Cambridge MA 02138-5801

Tel: (617) 496-3834

Fax: (617) 496-5747

jeffrey_frankel@harvard.edu

http://www.ksg.harvard.edu/fs/jfrankel
Andrew K. Rose

Haas School of Business

University of California

Berkeley, CA 94720-1900

Tel: (510) 642-6609

Fax: (510) 642-4700

arose@haas.berkeley.edu

http://haas.berkeley.edu/ arose

\begin{abstract}
$\underline{\text { Abstract }}$
To quantify the implications of common currencies for trade and income, we use data for over 200 countries and dependencies. In our two-stage approach, estimates at the first stage suggest that belonging to a currency union/board triples trade with other currency union members. Moreover, there is no evidence of trade-diversion. Our estimates at the second stage suggest that every one percent increase in a country's overall trade (relative to GDP) raises income per capita by at least one third of a percent. We combine the two estimates to quantify the effect of common currencies on output. Our results support the hypothesis that important beneficial effects of currency unions come through the promotion of trade.
\end{abstract}

JEL Classification Numbers: F11, F33, O40

Keywords: dollarization, growth, cross-section, empirical, output, union, board, monetary.

* Jeffrey Frankel is Harpel Professor, and Director of the NBER program in International Finance and Macroeconomics. Andrew Rose is Rocca Professor, Research Associate of the NBER, and Research Fellow of the CEPR. The data sets are available at Rose's web site. For catching computational errors, we thank Jacques Melitz and Dani Rodrik; for comments we thank: Alberto Alesina, Alan Deardorff, John Helliwell, Timothy Kehoe, Dani Rodrik, Torsten Persson, Romain Wacziarg, two helpful anonymous referees, and seminar participants at the Bundesbank, Columbia University, the European Central Bank, Goethe University, Harvard University, the Hoover Institute, LACEA Rio, Michigan, NBER IFM program, Notre Dame University, the Swiss National Bank, and Universidad Torcuato Di Tella. This paper is a condensed and updated version of NBER WP \#7857. 


\section{Introduction: Why Should Common Currencies affect Income?}

Twelve European countries have formally abandoned their national currencies and adopted a new currency, the euro. In 2000, Ecuador unilaterally abandoned its national currency and dollarized; in 2001 El Salvador followed suit. A number of countries have also adopted strict monetary regimes without literally abandoning the domestic currency. Hong Kong in 1984 and Argentina in 1991 tied their currencies tightly to the American dollar through currency board schemes, though the latter arrangement came to an unfortunate end ten years later. Now Estonia, Lithuania, Bulgaria, and Bosnia employ currency boards as well.

This paper is concerned with the question: What are the consequences for trade and income of a country giving up its independent currency by joining a currency union or currency board?

A currency union (or board) is most frequently thought of as a time-consistent monetary policy rule that countries use to achieve low inflation. When the central bank lacks credibility, the high inflation resulting from monetary discretion is reduced by means of an extreme monetary regime. ${ }^{1}$ Many economists think that the primary effect of currency unions and boards is via reduced inflation, with all its beneficial consequences. Of course, although lower inflation has many benefits, these regimes also have their costs in terms of macroeconomic stability. These costs may be large if a country adopts the currency of a country whose shocks are poorly correlated with domestic shocks.

There is another consequence of currency unions that may be of importance, however. By reducing the costs of international transactions, these extreme regimes promote trade and openness. The intuition is simple, and has been emphasized in the literature since at least Mundell [1961]: trade between areas that use a single money is cheaper and easier than trade 
between areas with their own monies. The trade induced by currency union may in turn have a beneficial effect on income. In this empirical paper, we quantify the importance of this second channel that currency union may have on output.

We proceed by investigating two relationships: the hypothesis that a currency union/board stimulates trade among its constituent units, and the hypothesis that trade in turn stimulates output. We then combine these results and estimate the effect that currency union/board has on the long-run level and rate of growth of real income, in a cross-section of countries.

We find two big results, each supplemented by a further, smaller, result. The first major finding is that common currencies promote bilateral trade. The additional smaller result is that common currencies also promote overall openness (i.e., the ratio of trade to GDP): there is no evidence that trade created among members of a currency union comes at the expense of a diversion of their trade away from non-members. The other major finding is that, by raising overall trade, currency unions also raise income. Here too there is an additional smaller result: we test and find no support for the common argument that currency unions improve income through other channels, e.g., by enhancing the central bank's credibility and/or stabilizing the macroeconomy. The effect appears to come via trade.

In section 2 below, we estimate the effect of currency unions and currency boards on openness. Section 3 provides estimates of the effects of openness on income, taking into account the likely endogeneity of trade. It also provides tests for alternative effects of currency union on income. Section 4 combines statistics to estimate the effect of "dollarizing" or adopting the euro for individual countries. After some sensitivity analysis and caveats, the paper ends with brief conclusions. 


\section{The Effects of Currency Union on Trade}

A popular argument against floating currencies - albeit one that most academic economists have been skeptical of - is that exchange rate variability creates uncertainty that discourages international trade and investment. Fixing the exchange rate eliminates this risk, and so promotes trade. Adopting a neighbor's currency as one's own is a credible commitment to exchange rate stability and has the extra advantage of eliminating transactions costs; both effects may give extra encouragement to trade. The objective of this section of the paper is to provide a quantitative estimate of the effect of currency union in promoting trade. ${ }^{2}$

One reason that academic economists have tended to downplay this argument is that much exchange rate risk can be hedged, through the use of derivatives. Another reason is that quite a few empirical studies of the effect of exchange rate volatility on both trade and investment find small or negligible effects. ${ }^{3}$ But this is in part because most of the early tests relied on time series data. It is difficult to estimate a relationship between exchange rate variability and trade using time-series data.

\section{A) The gravity model}

By contrast, cross-sectional approaches have had more success, especially if they include developing countries. In particular, the "gravity" model has been used to uncover a negative effect of bilateral exchange rate variability on bilateral trade in the 1960s and 1970s. ${ }^{4}$ Rose [2000] finds sharper and more persistent effects and also shows that belonging to a common currency area has a large impact, multiplying bilateral trade by an estimated factor of over three. Evidently there is a discrete large benefit from eliminating transactions costs and eliminating the 
possibility of future rate changes -- beyond the effect of reducing exchange rate variability to zero.

In the bare-bones gravity equation, trade between a pair of countries is modeled as an increasing function of their sizes and a decreasing function of the distance between the two countries. The framework is one of the more successful empirical models in economics: typically a reasonable proportion of the variation in trade is explained with an equation where the coefficients are economically sensible, and well-determined statistically. Since we are interested in estimating the effect of currency union on trade, the gravity model is a natural vehicle to use. Among many possible references, Frankel [1997] provides a thorough review of the model.

Table I reports the results of a number of different specifications of the gravity equation, augmented by different sets of controls. We are most interested in the coefficients on two dummy variables. The "Currency Union" variable is unity if the two countries belonged to a common currency area (such as Panama and the United States), and zero otherwise. "Currency Board" is unity if one of the countries uses the currency of the other in a currency board arrangement (such as Hong Kong and the United States). All specifications include the standard gravity regressors. We also include a variety of other controls to demonstrate the robustness of our results. The panel data set includes observations from almost 8,000 country-pair observations (from over 180 countries and territories) at five-year intervals from 1970 through 1995. Slightly over $1 \%$ of the observations involve trade between members of currency unions or currency board arrangements. The data set is described in more detail in the first appendix.

We estimate our equations with OLS. The standard errors reported are robust to clustered heterogeneity, and year-controls are included in the regression but their coefficients are not reported. 
The models of Table I fit well, explaining over sixty percent of the variation in the data. The coefficients for the traditional gravity determinants are highly significant statistically, and economically sensible. The estimated coefficient on log distance is slightly over -1 , indicating that trade between a pair of countries falls by about one percent for every one percent increase in the distance between them. The coefficient on size (log real GDP) is slightly less than unity; trade rises with size but (holding constant for income per capita) somewhat less than proportionately. That is, large countries are more self-sufficient. Income per capita has its own estimated effect. The coefficient, around 0.5 , indicates that rich countries trade more than poor.

Two countries that speak the same language trade more by a multiplicative factor of around 1.8 (=exp.6), as do countries that share a common land border. Belonging to a regional trading bloc also increases trade, as does a common colonial heritage and a historical link to a mother country. Areas in political union (such as France and its overseas departments) also trade more with each other. Landlocked and geographically large countries both trade less with everyone.

\section{B) The estimated effect of common currencies on bilateral trade}

The focus here is on the currency union and currency board coefficients at the top of the table. The coefficients for each are positive, significant and large. The currency union and board coefficients are also similar in size; we cannot reject the hypothesis that they are equal. ${ }^{5}$ We can think of no compelling theoretical reason why the effect of currency boards should be precisely the same as that of currency unions. While both are restrictive monetary regimes, currency unions typically make prices more transparent internationally than currency boards, and have lower transactions costs. They have also been historically more credible and long-lived 
institutions. Nevertheless, the empirical evidence seems strong; accordingly we impose that restriction from now on.

As we add controls for colonial, political, and FTA relationships, the coefficients fall from over 2 to 1.36 . This latter estimate still implies that when two units share a common currency, trade is multiplied by a factor of over three $(\exp (1.36)=3.9)$, similar to the estimate in Rose [2000]. Inspection of year-specific effects shows a small tendency for the coefficient to rise over time, between the 1970s and the 1990s.

A three-fold effect strikes those new to this literature as large, and indeed it is. But it is more plausible when one recalls the findings, for example, of McCallum [1995] and Helliwell [1998], that Canadian provinces are ten to twenty times more inclined to trade with each other than with US states, after holding constant for distance and size. The latter finding has received much attention because it cannot be easily explained by geographic, linguistic, or trade policy variables. ${ }^{6}$ High on the list of possible reasons why integration is so much higher between provinces within a federation such as Canada than between countries is the fact that the provinces share a common currency.

This massive "home bias" towards domestic trade characterizes our data set as well. ${ }^{7}$ It seems eminently plausible, given the paucity of other explanations, that some part of home bias is explained by the fact that trade across international borders usually entails trade between different monies. Our equations in effect show that the unexplained part of home bias can be reduced by measuring attributes that are shared by different areas both within and across countries, such as common language, trade policy and so forth. They show that the currency union variable ranks in magnitude and explanatory power roughly equal with the FTA variable, behind the colonial relationship, and ahead of common language and the residual political union 
effect. This claim is confirmed by Rose and van Wincoop [2001], who estimate that half the typical border barrier is due to different sovereign monies.

\section{C) Does the currency union effect vary with size?}

A natural question to ask is whether currency unions are more beneficial to bilateral trade in very small countries than in larger ones. We examined this possibility by dropping from the sample very small countries (e.g., those more than either one or two standard deviations below the average size), but found the currency union coefficient remained highly significant and positive. The results are also robust to omitting observations where the product of the sizes (defined as either population or GDP) is especially small, or where the difference is especially large. Thus, we have found no evidence that the relationships are sensitive with respect to size.

\section{D) Is there trade diversion?}

To check for the possibility that the stimulus to trade among members of a currency union comes at the expense of diversion of trade with non-members, we added a dummy variable that is unity when precisely one of the members of the pair belongs to a currency union or board. It turns out to show up with a statistically significant positive coefficient. Thus the evidence points toward trade creation rather than trade diversion. We corroborate this point in the working paper version using aggregate (rather than bilateral) trade data: countries that belong to currency unions are more open to trade overall.

To summarize, currency union seems to have a large effect in creating trade. To be conservative we assume below that a country that joins a currency union experiences a tripling in 
its trade with the other members of the union, although some of our estimates of this effect are even higher.

\section{The Effect of Trade on Income}

In this section of the paper, we estimate the effect of trade on income.

Classical trade theory gives us good reason to think that trade has a positive effect on the level of real income. New trade theory has made the field more realistic by introducing roles for increasing returns to scale, trade in imperfect substitutes, and endogenous technology. ${ }^{8}$ Some new trade theory also implies that open economies have higher long-run growth rates, rather than just higher income levels, since interaction with foreigners spurs innovation by speeding up the absorption of new ideas.

Quite a few empirical studies of growth rates across countries find that the ratio of trade to GDP, or some other measure of openness, is a significant determinant of growth. ${ }^{9}$ A typical specification begins with the determinants of output suggested by neoclassical growth theory, and adds a variable for exports as a share of GDP. ${ }^{10}$ In such empirical work, openness typically seems to have a positive and significant effect on the growth rate or level of income.

Interpreting a significant correlation between trade and growth as implying causality from the former to the latter is potentially problematic however, because of the serious problem of simultaneity bias. A number of studies have tangled with the challenge posed by simultaneity. Many studies have sought to identify measures of trade policy, hoping that they are exogenous. ${ }^{11}$ Even side from the serious difficulty of measuring trade policy, a fundamental conceptual problem of simultaneity remains [e.g., Sala-i-Martin, 1991]. Free-market trade policies may not per se be important to growth, but may be correlated with free-market domestic policies. In this 
case, liberal trade policies will be correlated with growth, even though they do not cause growth. There have also been other attempts to solve the problem with mixed results. Some have applied Granger-causality tests to the problem; others have attempted to use a simultaneous equation approach. As so often in macroeconometrics, however, the simultaneity problem has remained largely intractable.

What is needed is a good instrumental variable, which is exogenous yet highly correlated with trade. The gravity model offers a solution. Such variables as distance, populations, common borders, and common languages are plausibly exogenous. ${ }^{12}$ Yet these variables are highly correlated with trade, and thus make good instrumental variables. We use an intuitive two-step implementation of this idea. In the first stage, we estimate bilateral trade equations using the exogenous regressors in a gravity model. We then aggregate (the exponential of) the fitted values of bilateral trade across a country's trading partners, to create a prediction of its overall trade. In the second stage we use this predicted trade variable as an instrument for actual trade in an output equation. If trade still appears to be a significant determinant of output with instrumental variable estimates, then the effect of trade on output is plausibly causal.

This procedure has been implemented in Frankel and Romer [1999], who find that the effect of trade on output actually increases after correcting for simultaneity. ${ }^{13}$ Irwin and Tervio [2000] have used the same technique on eight observations spread between 1913 and 1990, and have again found that the trade variable has a highly significant effect on income (except for two inter-war years), with a magnitude comparable to that of Frankel and Romer. 


\section{A) The growth equation}

The convergence hypothesis in the growth literature dictates that income at the end of a period depends on income at the beginning of the period, with a tendency to regress gradually toward some long-run steady state. Convergence is conditional if it is present only after conditioning on variables such as factor accumulation. ${ }^{14}$

Although we consider a number of variants, our approach is based on an equation for which Mankiw, Romer, and Weil [1992] provide theoretical and empirical support. Our basic specification is:

$$
\begin{aligned}
& \ln (\mathrm{Y} / \mathrm{Pop})_{90, \mathrm{i}}=\alpha([\mathrm{X}+\mathrm{M}] / \mathrm{Y})_{90, \mathrm{i}}+\beta_{0}+\beta_{1} \ln (\mathrm{Pop})_{\mathrm{i}}+\phi Z_{\mathrm{i}} \\
& +\not \ln (\mathrm{Y} / \mathrm{Pop})_{70, \mathrm{i}}+\delta_{1}(\mathrm{I} / \mathrm{Y})_{\mathrm{i}}+\delta_{2} \mathrm{n}_{\mathrm{i}}+\delta_{3} \mathrm{School}_{\mathrm{i}}+\delta_{4} \mathrm{School}_{\mathrm{i}}+\mathrm{u}_{\mathrm{i}}
\end{aligned}
$$

where: the dependent variable is the natural logarithm of GDP (Y) divided by total population (Pop) at the end of 1990, measured in real PPP-adjusted dollars for country i; aggregate exports, aggregate imports, and gross investment are denoted "X", " $\mathrm{M}$ " and "I" respectively; the growth rate of population is denoted "n"; "School1" and "School2" are estimates of human capital investment based, respectively, on primary and secondary schooling enrollment rates; "Z" denotes other controls; Greek letters denote coefficients; and " $u$ " denotes the residual impact of other, hopefully orthogonal influences. Variables other than GDP per capita and openness are computed as averages over the sample period. Following the norm in the growth literature, we measure openness as the ratio of trade to output. The coefficient of interest to us is $\alpha$, the effect of openness on output.

We call "controls" the variables that derive from neoclassical growth theory and appear on the second line of the equation: initial income, investment, human capital and population 
growth. Frankel and Romer [1999] and Irwin and Tervio [2000] adopt a more stripped-down

specification by omitting these controls, following Hall and Jones [1999]. They simply regress output per capita against openness and measures of country size, reasoning that the factor accumulation variables might be endogenous. Including these controls in the output equation might result in a downward-biased estimate of $\alpha$, if some of the effect of openness arrives via factor accumulation. However, inappropriately excluding these variables would also produce biased results and could be expected improperly to attribute too large an effect to trade. Consequently we estimate our equation both with and without controls and try to be conservative in our interpretation. Our own preference is for the specification that includes the controls, in part because it is likely to avoid a possible upward bias in the openness coefficient.

\section{B) OLS results}

We begin by estimating our output equation with OLS to replicate the common finding that there is a statistical association between trade and income. In Table II, we report OLS estimates of the impact of trade on output both with and without factor accumulation controls.

Population size has a positive and statistically significant influence whether we include controls or not, confirming that larger countries are better able to take advantage of scale economies and/or resource diversity. Population enters with a coefficient of around 0.1 . This suggests that the smallest country in the sample derives a per capita income disadvantage relative to the mean country of around 49 per cent $[=0.1(8.6-3.7)]$. Size matters.

The key estimate in the income equation, however, is the coefficient of openness. The estimate is positive, statistically significant, and economically large. The results hold whether we include controls (in which case the coefficient is 0.33 ) or not (0.79). 
As already noted, the openness variable may be standing in for factor accumulation variables or other national characteristics and initial conditions less easily measured. We want to hold constant for variables such as investment, even knowing that we run the opposite risk of then failing to give credit to openness for some effect on income that comes via factor accumulation. When initial GDP, along with investment and other standard growth controls, is included, its coefficient is a highly significant 0.71 , representing a plausible degree of conditional convergence -- about 30 percent over a 20 -year period. The estimated coefficient on trade, 0.33 in the OLS version, says that, holding constant for 1970 income, income in 1990 was $1 / 3$ per cent higher for every 1.0 percentage point increase in the trade/GDP ratio. As expected, this effect is smaller than when we did not control for initial income. When multiplied by 3.45 $(=1 /(1-.71))$ to convert to an estimated effect on long-run income, the effect on output is 1.14 per cent for every 1.0 percentage point increase in openness.

Parenthetically, the effects of investment and both schooling variables are statistically significant and reasonable. Population growth has the negative sign hypothesized by the neoclassical model, but as in earlier work is the one growth determinant that is not statistically significant.

\section{C) Instrumental Variable Results}

The next step is to estimate the corresponding output equation estimates using IV estimation to account for the possible endogeneity of openness. The aggregated instrumental variable we choose comes from a simple gravity model that uses determinants of the log of bilateral trade: the log of distance, the log of partner country population, the log of area, and dummy variables for common language, common land border, and landlocked status. (The first 
stage is presented at the bottom of Table II.) After estimating the gravity model, we aggregate the exponent of the fitted values across bilateral trading partners to arrive at an estimate of total trade for a given country. The correlation between actual trade shares and our generated instrument is a reassuringly high value of $.72 .^{15}$

The estimate of interest to us is $\alpha$, the coefficient on openness. When initial income and other controls are not included, the coefficient is estimated to be a statistically significant 1.61 . When we include controls, the effect of trade on output is 0.43 . The implied steady state impact is $1.6(=.43 /(1-.73))$, similar to the estimate without the controls. These effects are economically and statistically significant. Both IV estimates are a bit higher than their OLS analogues (the opposite of what simultaneity bias leads one to expect). However, the IV estimates are not significantly different from the OLS results: Hausman tests do not reject the hypothesis of equal slopes. Thus, we see little evidence that our results are affected by reverse causality running from income to openness.

Table II also shows that adding the log of land area as another measure of country size does not destroy the finding of a large effect of openness on output. Land area only enters positively in the version without controls, where its coefficient is insignificantly different from zero. The presence of land raises the openness coefficient in the version without controls, and lowers it in the version with controls; both changes are insignificant.

To summarize, we have found that openness seems to have a positive effect on real income per capita. Our results seem robust and both economically and statistically significant. To be conservative, we use 0.33 in our calculations below (our OLS estimate of the effect of trade on output over a twenty-year period). This is lower than both our IV and (especially) our 
steady-state effects. ${ }^{16}$ It is important to be conservative since we are acting on the assumption that policy- and naturally-induced trade openness have similar effects on income. ${ }^{17}$

\section{D) Sensitivity Analysis: Geography, and Institutions}

Rodriguez and Rodrik [2000] have argued that geographically constructed instrumental variables such as the one used here might be incorrectly appropriating some direct influences of geography on income. More directly, Rodrik [2000] has argued that our results may be affected by the exclusion of small city-states and/or measures of institutional quality. We now perform sensitivity analysis to show that our results seem robust to both criticisms.

Our sensitivity analysis is presented in two tables. The results reported in Table IIIa do not include measures of factor accumulation, while those in Table IIIb do control for factor accumulation. ${ }^{18}$ We use instrumental variables for all estimates presented in Table III.

In the extreme left column, we report our benchmark results from Table II, simply for the purpose of comparison. In the next column, we report the effect of dropping Singapore and Hong Kong, two small city-states with high levels of both openness and GDP/capita. We then add a number of variables to see whether openness is appropriating some other effect whose absence masks the true unimportance of openness. Thus our second sensitivity check is to add the (natural logarithm of) distance to the equator (suggested by Hall and Jones, 1999). Next we add a dummy variable that is unity for countries with significant percentages of their land area inside the tropics (as proposed by Radelet et al. 1997). Our fourth check is to add continental dummies for Latin America, East Asia and Sub-Saharan Africa. Finally, we add Rodrik's measure of institutional quality. ${ }^{19}$ 
The coefficient on openness remains significant - and in fact turns out to be higher in estimated magnitude - when the city-states are excluded; its t-statistic is 3.9 without controls, and a more marginal 1.9 when controls are included. Distance from the equator appears with a positive coefficient, as expected, though it is only significant when we do not include extra income controls. The tropical variable has a negative and significant coefficient, as expected. Dummy variables for Latin America, East Asia, and sub-Saharan Africa appear significantly in our equation without controls. Thus, the effects identified by Rodriguez and Rodrik are confirmed. Still, the key question concerns the implications of these perturbations for the openness variable. In every case, regardless whether the other controls are included or not, the openness variable retains most of its magnitude and all of its statistical significance in the presence of each of the three Rodriguez-Rodrik modifications. The t-statistics are 3 to 4 .

The measures of institutional quality are statistically significant when included in the income equation without initial income and the other controls, and are especially so when entered in the form of a rescaled combined single variable. None is significant when included alongside initial income and the other factor accumulation variables. However, again, the key question is the implication for the openness coefficient, which remains positive with a t-statistic around 3 , under each of these specifications.

We conclude from this that our finding of a positive and significant effect of openness on income seems robust to a number of perturbations to our methodology.

\section{E) Does Currency Union Affect Income Other Than Via Trade?}

Thus far we have examined the effect that currency unions have on income through their effect on openness. But perhaps currency unions have a growth effect via a completely different channel. In most of the literature on currency unions, the advantage that is emphasized is not the 
convenience to importers and exporters of abolishing currency distinctions. ${ }^{20}$ Rather the emphasis is on the credibility benefits derived when the central bank "ties its hands" with a rigid institutional commitment to monetary stability. ${ }^{21}$

These models generally imply that the choice of an anchor currency for a small country to adopt doesn't matter, so long as it is a strong and stable currency. In this view, there is no clear advantage in choosing the currency of a country that is a natural trading partner. In our trade-based approach, on the other hand, it should make a big difference with which country one forms a currency union.

We look for possible non-trade effects by including measures of currency union directly in the income equation. We do this in a number of different ways that are designed to isolate the enhancement of trade (or other economic interactions with major partners).

First, we add to the output equation in Table II a dummy variable that is unity if the country was a member of a common currency area in 1990, and zero otherwise. The results in Table II indicate that the effect of these regimes is negative; significantly so when we omit controls, insignificantly different from zero if we include controls. We also add the country's average inflation rate to these regressions, but the results are not substantively changed. ${ }^{22}$ Indeed, the currency union/board dummy remains negative even when the openness variable is dropped. Apparently currency union in and of itself does not raise income, as one would expect it would if it improved monetary credibility and stability.

Our hypothesis is that the failure to find evidence that currency unions or boards per se have a positive effect on real income stems from the fact that a simple dummy variable does not take account of how many partner countries are in the currency union and how important they are to the domestic country. A currency union with the United States should do more for most 
countries than a currency union with New Zealand. Thus in Table IV, we include the inner product of bilateral currency union membership with different measures of the importance of the bilateral partners. The importance of the bilateral partners in a currency union can be measured by the key determinants of bilateral trade such as size and proximity.

The results in Table IV show that a country does not derive an income advantage from belonging to a currency union (or board) per se. The coefficient estimate is even negative, and appears statistically different from zero. ${ }^{23}$

The emphasis here is instead on the importance of a country's currency union partners. We begin by entering the inner product of bilateral currency union membership and the real GDP of the bilateral trading partner. That is, we add $\sum_{j} C U_{i j} Y_{j}$ where $C U_{i j}$ is unity if countries $i$ and $j$ were in a common currency area, and zero otherwise, and where $Y_{j}$ denotes the real GDP of country $j$. A high value of this inner product indicates that country $i$ is in a currency union with large countries; we expect this to benefit the trade and hence output of country $i$ accordingly. The inner product does indeed have an economically and statistically significant positive effect on income, when we do not include controls. Since our gravity estimates indicate that trade depends not only on partner output, but also on the reciprocal of distance, we also try the aggregate ratio of union partners' output to distance, i.e., $\sum_{j} C U_{i j}\left(Y_{j} /\right.$ Dist $\left._{i j}\right)$ where Dist $_{i j}$ is the distance between countries $i$ and $j .{ }^{24}$ Again the coefficient is large, positive and significant in the case without controls. When we include controls, all the inner product coefficients are still positive, although none is significant.

If the currency union dummy had worked positively in the growth equation regardless of the trade-inducing nature of the union partner, it would have suggested that the benefits come through the central bank credibility route. Our results instead support the notion that the 
currency union effect on income comes through the trade route. Our results on the inner product effects could be described as mixed, since they are insignificant when we include our controls. Nevertheless, there is little support here for the notion that belonging to a currency union per se is good for growth regardless of the partner. Rather, some evidence indicates that it matters whether the currency union includes important trade partners. ${ }^{25}$

\section{The Effects of Currency Unions on Income}

In this section we put together the estimates of the two stages - the effect of currency union on trade, and the effect of trade on output - to estimate the effect of currency union, through trade, on output.

If the benefits of currency union resulted solely from monetary stability, the composition of a currency union would not matter, so long as the anchor currency is strong and stable. In our view, however, geography is highly relevant to the makeup of common currency areas. Countries tend naturally to trade more with large neighbors; thus the benefits to adopting the currency of a large neighbor will exceed the benefits to adopting the currency of a country that is smaller or more distant, other things equal.

One way to proceed would be to estimate first the effect of currency union on an average country's trade, and then estimate the effect of this additional trade on an average country's output. While we pursue this tack in the working paper version (and find that the average effect of a currency union on output is about 4\%), we do not consider this to be the calculation of most interest. As noted, the effect of currency union on openness depends on who else is in the currency union. The boost to trade (and therefore output) will be stronger if the currency union partner is one with whom one trades, because it is large, nearby, or because of other links (e.g., 
linguistic or historical). Lithuania will boost its total trade and output more by adopting the euro than by adopting the New Zealand dollar.

Table V provides the answers for individual countries to the questions of interest: "What is the estimated effect on trade and output of adopting the dollar as the legal currency?" and "What would be the predicted effect of adopting the euro?"

The first two columns of Table V show the shares of trade in 1995 that selected countries (on rows) conducted, with the dollar zone (the United States and other countries that use the dollar such as Panama) and EMU respectively. The third column reports the total trade of the country as a percentage of GDP.

We use the data of the first three columns to estimate the effects of the country dollarizing or joining EMU on trade and output in the four columns at the right of the table. These rely on two estimates: the effect of currency union on a) trade and b) output. For the former, we use our bilateral gravity estimate from section 2, which predicts that currency union triples trade with other members of the union (with no trade-diversion). For the latter, we use our conservative estimate from section 3 that each percentage point increase in trade/GDP raises real GDP per capita by one third of a percent over the subsequent 20 years.

Thus in column four we show the effect (expressed as a percentage of GDP) on total trade that occurs when dollarization triples trade with the dollar zone. For instance, since Albania's trade was 47 percent of GDP, a tripling of the 3 percent of this trade that was conducted with the dollar zone would lead Albania's trade to rise by three percent of GDP $(.47 * .03 * 2=.028)$. Then, multiplying this effect by a third gives the effect of dollarization on Albania's real GDP per capita, an increase of one percent. Columns six and seven tabulate the 
analogous effects of adopting the euro. Unweighted averages are provided at the bottom of the table to provide a quick summary.

Although one should view these estimates as illustrative, they are not without interest. To continue with our example, Albania would gain far more from adopting the euro, with an estimated eventual boost to real income per capita of over twenty percent. Because Albania's natural trading partners are in Europe, a tripling of its trade with the euro bloc does far more for its overall trade than does dollarization.

\section{Three Important Qualifications}

While our results appear in many ways quite strong, we must register three important qualifications.

First, we have not here provided any evidence regarding time lags in the effects of adopting a currency union on trade patterns. Ours is primarily a cross-section study. Thus we cannot tell how long it may take for a currency union to attain the large effects that we estimate. $^{26}$ Using a 1948-1997 sample that includes a number of countries that left currency unions during that period, Glick and Rose (2001) find that trade among the members was twice as high in the currency union period as afterwards. This suggests that roughly two thirds of the tripling effect may be reached within three decades of a change in regime.

Secondly, the decision to adopt a common currency could be endogenous. In other words, the observed correlation between currency links and trade links could come about because both are determined by some third factor. Indeed, that is precisely the point of much of the existing currency union literature. In the trade equations of Table I, we have controlled for the third factors that come to mind -- common language, colonial history, political union, and so 
on -- and the currency effect remains almost as strong as ever. Nevertheless, it is certainly possible that an element of endogeneity remains in the currency union/board variable. While we do not believe that our results can be explained away by endogeneity, we know of no way to eliminate effectively the possibility that simultaneity bias results in an over-estimate of the effect of currency unions on trade. The reason is that plausible instrumental variables for currency union membership do not appear to exist in practice. Persson [2001] uses non-standard techniques in an effort to address the importance of this issue, and finds that the effect of currency union on trade is reduced, but Rose [2001] has a response. ${ }^{27}$

Third is the question whether our results apply only to small countries and dependencies. Our data set relies heavily on small and/or poor countries and dependencies, because these are the only ones that were in currency unions and currency boards (prior to the launch of EMU in 1999). Canada's proximity and naturally high level of trade with the United States mean that, according to the numbers in our table, adopting the US dollar would provide a large boost to Canadian trade and output. Still, for Canada and a number of other major countries, the effects estimated in Table V seem implausibly large. Perhaps our estimates are inapplicable to larger countries?

Recall from Section II.C that we divided our sample of CU members into those that were very small and those that were merely small, and found no difference in the effects on trade in the gravity model. But the largest country in that set is Ireland (or, when currency boards are included, Argentina). None is as large as one of the major industrialized countries.

Intuition tells us that the dependence of income on trade and size may be non-linear. Perhaps a country needs access to a market that is of at least a certain threshold size, after which the benefits of economies of scale are no longer so large. Allowing for such non-linearities 
might help produce estimates more relevant to larger countries, and would be of intrinsic interest for small territories and countries that contemplate entering or leaving currency unions or political unions. One suspects that such tiny units as Gibraltar, Gaza, and Guam, are not economically viable on their own, and are highly dependent on international trade. If a country makes it past a certain threshold in size, perhaps it is no longer so dependent on trade? And perhaps Ireland, the Ivory Coast and Panama are also below that threshold?

We can test the non-linearity proposition, and in doing so are no longer limited to small and very small countries, since we are no longer limited to members of currency unions. We checked for a non-linear effect of openness on income in a few different ways. When we split the entire sample in half according to the size of the population, we found that openness was large and significant for both large countries and small; indeed the coefficients are larger for larger countries. Also, adding a quadratic term for openness does not remove the finding of a large positive impact of trade on output. That is, there is no evidence that our results depend on our assumption that the effect of openness on income is linear.

To repeat, we have found no reason to believe that the effects of currency unions diminish with size. Nevertheless, we emphasize that there have been no currency unions in the modern era that involve large rich countries (until EMU). If currency unions among the large and rich have completely different effects from unions among small or poor countries, there is simply no way to know this with historical data.

\section{Summary and Conclusion}

Using a large data set of economic and geographic variables for over 200 countries and dependencies, we have quantified the implications of currency unions for trade and output using 
a two-stage approach. Our results at each stage have been robust and significant, both statistically and economically. Our estimates at the first stage suggest that a currency union triples trade with the partners in question. Furthermore, there is no evidence of diversion of trade away from non-members. Thus the currency union boosts a country's total trade. Our estimates at the second stage suggest that every one percent increase in total trade (relative to GDP) raises income per capita by at least one third of a percent over a twenty-year period, and possibly by much more over the long run. We put the two estimates together to estimate the effect of a currency union on output. Our results suggest that a country like Poland, which conducts half its trade with the euro zone, could eventually boost income per capita by a fifth by joining EMU.

Our estimates seem very large, and we try not to take them too literally. Rather we hope they shift the terms of the debate on common currencies towards a more serious consideration of the somewhat neglected trade benefit.

Scale is important to an economy, whether it is attained by the intrinsic size of the political unit, by political union with a larger country, or by international trade. Currency unions seem to provide a significant stimulus to trade, and thereby to economic performance. But it matters with whom one enters a currency union. Much of the literature on exchange rate regimes focuses on the requirements that currency union partner(s) have a stable currency and be subjected to shocks correlated with those of the domestic country. While we do not disagree with these ideas, our results also suggest that the currency should belong to a country (or set of countries) that is a natural trading partner, by virtue of size, proximity, and/or other linkages.

These results are subject to many caveats. We don't yet know how quickly countries reap the trade-boosting effects of currency unions. We can't be sure that the same effects we have estimated for a collection of mostly small and/or poor countries can be extended to large, 
rich countries (such as those in EMU). Despite our attempts to hold constant for a number of factors, we don't know if the currency union/board variable might still be appropriating some of the influence of cultural or historical links that we have yet to measure, or the effects of business cycle synchronization. It is also possible that some of the output effect comes through other geographic interactions that also run along gravity lines. Still, we find it reassuring that the currency union has a positive effect on income when included directly in the income equation, if and only if it is weighted by the importance of trading partners. This suggests that the benefit does not come from monetary stability. And we have found no evidence that currency union per se has a positive significant effect on output.

Finally we should make it clear that we have not concerned ourselves with most arguments for or against currency unions - for example that the loss of monetary independence makes it impossible to respond to idiosyncratic shocks. Rather, we have quantified a potential benefit of currency unions that has been under-examined in the literature. 


\section{Appendix: A Description of the Data Sets}

We employ two data sets in this paper. The first is used to estimate the bilateral gravity models of trade, and thereby to model the effect of currency union on trade. The second is used to estimate the impact of trade on output.

The first (trade) data set consists of 41,678 bilateral trade observations spanning six different years [1970, 1975, 1980, 1985, 1990, and 1995). We are missing observations for some of the regressors so the usable sample is smaller for most purposes. All 186 countries, dependencies, territories, overseas departments, colonies, and so forth for which the United Nations Statistical Office collects international trade data are included in the data set. For convenience, we refer to all of these geographical units as "countries." The trade data are taken from the World Trade Database, a consistent recompilation of the UN trade data presented in Feenstra, Lipsey and Bowen [1997], augmented with data from the UN's International Trade Statistics Yearbook. This data set is estimated to cover at least $98 \%$ of all trade. The nominal trade values (recorded in thousands of American dollars) have been deflated by the American GDP chain price index. In this data set, there are 406 country-pair observations where there is trade between two members of a currency union, and 20 observations where one country uses the currency of another in a currency board arrangement. The currency unions and boards are tabulated below, in Table A I.

We use the Penn World Table (PWT) 5.6 for population and real GDP per capita data, filled in with data from the World Bank World Development Indicators (taken from the 1998 WDI CD-ROM) where the former is missing (e.g., for 1995, where the Penn World Table data set is unavailable). For location (used to calculate Great Circle distance and contiguity), official language, colonial background, and other such information, we use information taken from the CIA's web site. A number of regional free trade agreements are included in the FTA dummy: the EEC/EC; the Canada-US FTA; EFTA; the Australia/New Zealand closer economic relationship; the Israeli/US FTA; ASEAN; CACM; PATCRA; CARICOM; SPARTECA; and the Cartagena Agreement, using information at the WTO's web site.

The second macroeconomic data set consists of annual observations for 210 "countries" between 1960 and 1996 extracted from the 1998 World Bank World Development Indicators (WDI) CDROM, merged with data from the Penn World Table (PWT) Mark 5.6. For most purposes, the sample starts in 1970 and ends in 1990 or 1992. A maximum of 7,803 observations is available (not all countries exist for the entire data sample). For both the WDI and the PWT data sets, we use all available observations (by which we mean the comprehensive set of years, countries, territories, colonies and other entities covered). There are numerous missing observations for variables of interest. The data set has been checked and corrected for mistakes. In this data set, there are 1,891 observations for countries that were members of a currency union.

Jeffrey A. Frankel

Kennedy School of Government

Harvard University
Andrew K. Rose

Haas School of Business

University of California 


\section{References}

Alesina, Alberto and Robert Barro, “Currency Unions,” NBER Working Paper No. 7927 (2000).

Anderson, James E., and Eric van Wincoop, "Gravity with Gravitas: A Solution to the Border Puzzle,” NBER Working Paper No. 8079, 2001.

Barro, Robert, "Economic Growth in a Cross Section of Countries," Quarterly Journal of Economics, CVI (May 1991), 407-444.

Barro, Robert, and Xavier Sala-i-Martin, "Convergence," Journal of Political Economy, C, no. 21, 223-251 (April 1992).

Dollar, David, “Outward-oriented Developing Economies Really Do Grow More Rapidly: Evidence from 95 LDCs: 1976-1985," Economic Development and Cultural Change, XL, 523- 544 (1992).

Edison, Hali, and Michael Melvin, "The Determinants and Implications of the Choice of An Exchange Rate System," in Monetary Policy For a Volatile Global Economy, W. Haraf and T. Willett, eds. (Washington, DC: American Enterprise Institute, 1990).

Edwards, Sebastian "Openness, Trade Liberalization and Growth in Developing Countries," Journal of Economic Literature, XXXI, no. 3, 1358-93 (September, 1993a).

----- "Trade Policy, Exchange Rates, and Growth," in R. Dornbusch and S. Edwards, eds., Reform, Recovery and Growth: Latin America and the Middle East (Chicago, IL: University of Chicago Press, 1993b), pp. 13-49.

Fischer, Stanley "Growth, Macroeconomics and Development," in O. Blanchard and S. Fischer, eds., NBER Macroeconomics Annual 1991 (Cambridge, MA: MIT Press, 1961), 329-64.

----- "The Role of Macroeconomic Factors in Growth." Journal of Monetary Economics, XXXII, no. 3 (Jan. 1993), 485-512.

Frankel, Jeffrey, Regional Trading Blocs (Washington, DC: Institute for International Economics, 1997).

Frankel, Jeffrey, and David Romer, "Does Trade Cause Growth?” American Economic Review, 89, no. 3 (June 1999), 379-399.

Frankel, Jeffrey, David Romer, and Teresa Cyrus, "Trade and Growth in East Asian Countries: Cause and Effect?" NBER Working Paper No. 5732 (August 1996). In NICs After Asian Miracle, New World Order Series, vol. 23, edited by H. Singer, N. Hatti and R.Tandon (India: BRPublishing Corporation, Ltd., forthcoming).

Frankel, Jeffrey, and Shang-Jin Wei "Emerging Currency Blocs," in The International Monetary 
System: ItsInstitutions and its Future, edited by Hans Genberg (Springer: Berlin, 1995), 111143.

Ghosh, Atish, Ann-Marie Gulde, and Holger Wolf, "Currency Boards -- More Than a Quick Fix?”Economic Policy, 31 (Oct. 2000), 270-335.

Glick, Reuven, and Andrew Rose, "Does a Currency Union Affect Trade? The Time Series Evidence," NBER Working Paper No. 8396, July 2001.

Grossman, Gene, and Elhanan Helpman, Innovation and Growth in the Global Economy (Cambridge MA: MIT Press, 1991a).

Grossman, Gene, and Elhanan Helpman, "Trade, Knowledge Spillovers, and Growth" European Economic Review 35, no. 2-3, April, 517-526, (April 1991b).

Hall, Robert, and Charles Jones, "Why Do Some Countries Produce So Much More Output per Worker than Others?" Quarterly Journal of Economics, 114, no.1 (Feb. 1999), 83-116.

Helpman, Elhanan, "Growth, Technological Progress, and Trade," National Bureau of Economic Research Reprint no. 1145 (1988).

Helpman, Elhanan, and Paul Krugman, Market Structure and Foreign Trade (Cambridge, MA: MIT Press, 1985).

Helliwell, John, How Much Do National Borders Matter? (Washington DC: Brookings Institution, 1998).

Irwin, Douglas, and Marko Tervio "Does Trade Raise Income? Evidence from the Twentieth Century,” NBER Working Paper 7745 (2000).

Levy-Yeyati, Eduardo, and Federico Sturzenegger, "To Float or to Trail: Evidence on the Impact of Exchange Rate Regimes," Universidad Torcuato de Tella; NBER Summer Institute (July 2001).

Mankiw, N. Gregory, David Romer and David Weil, "A Contribution to the Empirics of Economic Growth," Quarterly Journal of Economics CVII (1992), 407-437.

McCallum, John, "National Borders Matter: Canada-U.S. Regional Trade Patterns," American Economic Review 85, no.3 (June 1995), 615-623.

Mundell, Robert A., 1961, “Optimum Currency Areas,” American Economic Review, 51, 509517.

Persson, Torsten, 2001, "Currency Unions and Trade: How Large is the Treatment Effect?" Economic Policy, forthcoming. 
Rodríguez, Francisco, and Dani Rodrik “Trade Policy and Economic Growth: A Skeptic's Guide to the Cross-National Evidence," NBER Macroeconomics Annual 2001 (Cambridge, MA:

MIT Press, 2001).

Rodrik, Dani, "Getting Interventions Right: How South Korea and Taiwan Grew Rich," 20th Panel Meeting of Economic Policy; NBER Working Paper No. 4964 (December 1994).

----- "Comment on Frankel and Rose," unpublished, Kennedy School of Government, Harvard University (2000).

Romer, Paul, "What Determines the Rate of Growth and Technical Change?" World Bank Working Paper No. 279 (1989).

Rose, Andrew, “One Money, One Market? The Effect of Common Currencies on International Trade," Economic Policy (2000).

----- "Currency Unions and Trade: The Effect is Large" forthcoming Economic Policy (2001).

Rose, Andrew, and Eric van Wincoop, "National Money as a Barrier to Trade: The Real Case for Currency Union,” American Economic Association Papers and Proceedings (2001).

Sala-i-Martin, Xavier, "Comment," NBER Macroeconomics Annual 6 (Cambridge, MA: MIT Press, 1991), 368-378.

Summers, Robert, and Alan Heston "A New Set of International Comparison of Real Product and Price Levels: Estimates for 130 countries, 1950-85" Review of Income and Wealth 34, (March 1988), 1-26. 
TABLE I

The Effect of Currency Unions and Boards on Bilateral Trade

\begin{tabular}{|c|c|c|c|c|c|}
\hline Currency Union Dummy & $\begin{array}{l}2.11 \\
(.19)\end{array}$ & $\begin{array}{l}1.78 \\
(.18)\end{array}$ & $\begin{array}{l}1.38 \\
(.19)\end{array}$ & & \\
\hline \multirow[t]{2}{*}{ Currency Board Dummy } & 2.08 & 1.45 & .93 & & \\
\hline & $(.52)$ & $(.32)$ & $(.29)$ & & \\
\hline \multirow[t]{2}{*}{ Currency Union or Board Dummy } & & & & 1.36 & 1.55 \\
\hline & & & & $(.18)$ & $(.18)$ \\
\hline \multirow[t]{2}{*}{ Log Distance } & -1.22 & -1.11 & -1.06 & -1.06 & -1.08 \\
\hline & $(.02)$ & $(.03)$ & $(.03)$ & $(.03)$ & $(.03)$ \\
\hline \multirow[t]{2}{*}{ Log Product Real GDP } & .78 & .95 & .94 & .94 & .96 \\
\hline & $(.01)$ & $(.01)$ & $(.01)$ & $(.01)$ & $(.01)$ \\
\hline \multirow[t]{2}{*}{ Log Product Real GDP/capita } & .66 & .47 & .48 & .48 & .45 \\
\hline & $(.02)$ & $(.02)$ & $(.02)$ & $(.02)$ & $(.02)$ \\
\hline \multirow[t]{2}{*}{ Common Land Border Dummy } & & .61 & .63 & .63 & .63 \\
\hline & & $(.13)$ & $(.12)$ & $(.12)$ & $(.13)$ \\
\hline \multirow[t]{2}{*}{ Number land-locked $(0,1$ or 2$)$} & & -.36 & -.32 & -.32 & -.30 \\
\hline & & $(.04)$ & $(.04)$ & $(.04)$ & $(.04)$ \\
\hline \multirow[t]{2}{*}{ Log of Product of Land Area } & & -.17 & -.15 & -.15 & -.15 \\
\hline & & $(.01)$ & $(.01)$ & $(.01)$ & $(.01)$ \\
\hline \multirow[t]{2}{*}{ Common Language Dummy } & & .83 & .56 & .56 & .54 \\
\hline & & $(.06)$ & $(.06)$ & $(.06)$ & $(.06)$ \\
\hline \multirow[t]{2}{*}{ Common Colonizer Dummy } & & & .40 & .40 & .36 \\
\hline & & & $(.08)$ & $(.08)$ & $(.08)$ \\
\hline \multirow[t]{2}{*}{ Ex-Colony/Colonizer Dummy } & & & 1.95 & 1.95 & 1.77 \\
\hline & & & $(.13)$ & $(.13)$ & $(.13)$ \\
\hline \multirow[t]{2}{*}{ Political Union Dummy } & & & .96 & .97 & 1.05 \\
\hline & & & $(.37)$ & $(.36)$ & $(.37)$ \\
\hline \multirow[t]{2}{*}{ Common FTA Dummy } & & & 1.07 & 1.07 & 1.06 \\
\hline & & & $(.10)$ & $(.10)$ & $(.10)$ \\
\hline \multirow[t]{2}{*}{$\mathrm{CU}$ or $\mathrm{CB} /$ Non-CU and Non-CB Dummy } & & & & & .34 \\
\hline & & & & & $(.04)$ \\
\hline $\mathrm{R}^{2}$ & .61 & .63 & .64 & .64 & .64 \\
\hline RMSE & 2.05 & 2.00 & 1.97 & 1.97 & 1.97 \\
\hline
\end{tabular}

Regressand is log of bilateral trade in real American dollars.

UN trade data from 186 countries at five-year intervals, 1970-1995.

Number of Observations $=31,226$.

Year-specific fixed effects not reported.

Robust standard errors reported in parentheses. 


\begin{tabular}{|c|c|c|c|c|c|c|c|c|c|c|c|c|}
\hline & & The & ffec & Ope & $\begin{array}{l}\text { BLE } \\
\text { iess ol }\end{array}$ & Real & DP/ca & jita & & & & \\
\hline & OLS & IV & IV & IV & IV & OLS & OLS & IV & IV & IV & IV & OLS \\
\hline Openness & .79 & 1.61 & 1.96 & 1.59 & 1.70 & & .33 & .43 & .27 & .43 & .35 & \\
\hline & $\begin{array}{l}(.18) \\
.14\end{array}$ & $\begin{array}{l}(.52) \\
.23\end{array}$ & $\begin{array}{c}(.61) \\
.18\end{array}$ & $\begin{array}{c}(.48) \\
.18\end{array}$ & $\begin{array}{c}(.89) \\
.19\end{array}$ & & $\begin{array}{c}(.07) \\
07\end{array}$ & $\begin{array}{c}(.10) \\
.08\end{array}$ & $\begin{array}{c}(.11) \\
.10\end{array}$ & $\begin{array}{c}(.10) \\
.08\end{array}$ & $\begin{array}{c}(.13) \\
07\end{array}$ & \\
\hline & $(.06)$ & $(.08)$ & $(.11)$ & $(.08)$ & $(.12)$ & $(.05)$ & $(.02)$ & $(.02)$ & $(.03)$ & $(.02)$ & $(.03)$ & $(.02)$ \\
\hline Log Area & & & $\begin{array}{l}.11 \\
(.10)\end{array}$ & & & & & & $\begin{array}{l}-.05 \\
(.03)\end{array}$ & & & \\
\hline $\begin{array}{l}\text { Currency Union } \\
\text { or Board Dummy }\end{array}$ & & & & $\begin{array}{l}-.86 \\
(.22)\end{array}$ & $\begin{array}{l}-.76 \\
(.29)\end{array}$ & $\begin{array}{l}-.83 \\
(.27)\end{array}$ & & & & $\begin{array}{l}-.00 \\
(.09)\end{array}$ & $\begin{array}{l}-.05 \\
(.11)\end{array}$ & $\begin{array}{l}-.07 \\
(.10)\end{array}$ \\
\hline Mean Inflat & & & & & $\begin{array}{l}-.02 \\
(.05)\end{array}$ & $\begin{array}{l}-.08 \\
(.03)\end{array}$ & & & & & $\begin{array}{l}-.03 \\
(.02)\end{array}$ & $\begin{array}{l}-.04 \\
(.02)\end{array}$ \\
\hline Log '70 Real & & & & & & & $\begin{array}{l}.71 \\
(05)\end{array}$ & $\begin{array}{l}.73 \\
(06)\end{array}$ & .74 & $\begin{array}{r}.73 \\
(06)\end{array}$ & .73 & .70 \\
\hline Investment/GDP & & & & & & & .016 & .013 & .017 & .013 & .016 & .023 \\
\hline Ratio & & & & & & & $(.006)$ & $(.006)$ & $(.006)$ & $(.006)$ & $(.007)$ & $(.07)$ \\
\hline Population & & & & & & & -.06 & -.05 & -.04 & -.05 & -.03 & -.04 \\
\hline Growth Rate & & & & & & & $(.0$ & $(.06)$ & $(.0$ & $(.0$ & $(.0$ & $(.05)$ \\
\hline Primary & & & & & & & .002 & .001 & .002 & .001 & .002 & .002 \\
\hline Schooling Rate & & & & & & & $(.002)$ & $(.002)$ & $(.002)$ & $(.002)$ & $(.002)$ & $(.002)$ \\
\hline Secondary & & & & & & & .007 & .008 & .006 & .007 & .007 & .007 \\
\hline Schooling Rate & & & & & & & $(.002)$ & $(.003)$ & $(.002)$ & $(.003)$ & $(.003)$ & $(.002)$ \\
\hline $\begin{array}{r}\text { Number of } \\
\text { Observations }\end{array}$ & 115 & 110 & 109 & 110 & 100 & 105 & 106 & 102 & 102 & 102 & 96 & 100 \\
\hline$R^{2}$ & .11 & & & .07 & & & .9 & .9 & .9 & .9 & .9 & .93 \\
\hline RMSE & 1.02 & 1.08 & 1.14 & 1.04 & 1.11 & 1.11 & .28 & .28 & .28 & .28 & .28 & .29 \\
\hline
\end{tabular}

Regressand is log of Real GDP/capita in 1990, Penn World Table.

Intercepts not reported.

Robust standard errors reported in parentheses.

* Coefficients and standard errors for mean inflation multiplied by 100 .

\section{Instrumental Variable (First Stage) Generation}

$$
\begin{aligned}
& \left(\text { Trade }_{\mathrm{ij}} / \mathrm{GDP}_{\mathrm{i}}\right)=-.94 \log \left(\text { distance }_{\mathrm{ij}}\right)+.82 \log \left(\mathrm{pop}_{\mathrm{j}}\right)+.53 \text { ComLang }_{\mathrm{ij}} \\
& \text { (.05) } \\
& \text { (.02) } \\
& \text { (.11) } \\
& +.64 \text { ComBorder }_{\mathrm{ij}}-.27 \log \left(\text { Area }_{\mathrm{i}} \mathrm{Area}_{\mathrm{j}}\right)-.47 \text { \#Landlocked }_{\mathrm{ij}} \\
& \text { (.21) } \\
& \text { (.01) }
\end{aligned}
$$

Equation estimated for 1990. $\mathrm{R}^{2}=.28$; Number of Observations $=4052$.

Robust standard errors in parentheses; intercept not reported.

Correlation between trade ratio and generated IV $=.72$ 
TABLE III

The Effect of Openness on GDP/Capita, without Controls

Default Drop S, HK

$\begin{array}{lllllll}\text { Openness } & 1.61 & 4.1 & 1.28 & 1.13 & 1.23 & .68\end{array}$

$\begin{array}{llllll}(.52) & (1.1) & (.27) & (.22) & (.33) & (.23)\end{array}$

Log Distance from Equator

.58

$(.09)$

Tropical Dummy

$-1.62$

$(.15)$

Latin Dummy

$-.50$

$(.20)$

East Asian Dummy

$-1.14$

(.30)

Sub-Saharan Dummy

$-1.60$

Institutions

3.11

(.23)

Number of Observations $\quad 110$

108

110

106

110

91

RMSE $\quad 1.08$

1.30

.35

.55

$.49 \quad 56$

$\begin{array}{llll}.88 & .75 & .78 & .71\end{array}$

The Effect of Openness on GDP/Capita, with Factor Accumulation Controls Default Drop S, HK

Openness $\quad .43$

$(.10)$

Log Distance from Equator

Tropical Dummy

Latin Dummy

East Asian Dummy

Sub-Saharan Dummy

Institutions
.43

$(.10)$

.01

$(.04)$

$-.18$

(.09)

$-.15$

(.10)

.08

$(.19)$

$-.18$

$(.11)$

$\begin{array}{rrrrrrr}\text { Institutions } & & & & & & .22 \\ & & & & & & (.23) \\ \text { Number of Observations } & 102 & 100 & 102 & 101 & 102 & 89 \\ \mathrm{R}^{2} & .94 & .94 & .94 & .94 & .94 & .94 \\ \text { RMSE } & .28 & .30 & .28 & .28 & .28 & .28\end{array}$

IV estimation;

Regressand is log of Real GDP/capita in 1990, PWT.

Intercepts not reported.

Robust standard errors reported in parentheses. 
TABLE IV

The Effect of Currency Unions on GDP/capita

\begin{tabular}{|c|c|c|c|c|c|c|}
\hline $\begin{array}{r}\text { Factor Accumulation Controls? } \\
\text { Currency Union } \\
\text { Or Board }\end{array}$ & $\begin{array}{l}\text { No } \\
-.79 \\
(.27)\end{array}$ & $\begin{array}{l}\text { No } \\
-1.35 \\
(.21)\end{array}$ & $\begin{array}{l}\text { No } \\
-1.23 \\
(.24)\end{array}$ & $\begin{array}{l}\text { Yes } \\
.03 \\
(.11)\end{array}$ & $\begin{array}{l}\text { Yes } \\
-.07 \\
(.10)\end{array}$ & $\begin{array}{l}\text { Yes } \\
.01 \\
(.12)\end{array}$ \\
\hline Inner Product of Currency Union/Board and & & 1.2 & & & .25 & \\
\hline $\begin{array}{l}\text { Inner Product of Currency Union/Board and } \\
\text { (Real GDP/Distance)** }\end{array}$ & & & $\begin{array}{c}2.3 \\
(.88)\end{array}$ & & & $\begin{array}{l}.01 \\
(.3)\end{array}$ \\
\hline $\begin{array}{r}\text { Test for Joint Significance of both CU/CB } \\
\text { terms ( } p \text {-value) }\end{array}$ & & .00 & .00 & & .50 & .99 \\
\hline Number of Observations & 115 & 108 & 108 & 106 & 102 & 102 \\
\hline $\mathrm{R}^{2}$ & .07 & .18 & .15 & .92 & .92 & .92 \\
\hline RMSE & 1.04 & .99 & 1.01 & .32 & .32 & .33 \\
\hline
\end{tabular}

Regressand is log of Real GDP/capita in 1990, PWT.

OLS. Controls, and intercepts not reported.

Robust standard errors reported in parentheses.

* Coefficient and standard error multiplied by $\mathrm{e}^{10}$

** Coefficient and standard error multiplied by $\mathrm{e}^{7}$ 
TABLE V

Predicted Effects of Dollarization and Euro-adoption on Trade and Output (Selected countries)

\begin{tabular}{|c|c|c|c|c|c|c|c|}
\hline & \multirow{2}{*}{\multicolumn{2}{|c|}{ \% '95 Trade with: }} & \multicolumn{5}{|c|}{ Potential Effects (\% GDP) of: } \\
\hline & & & \multirow{2}{*}{$\begin{array}{l}\text { '95 Trade } \\
\text { (\% GDP) }\end{array}$} & \multicolumn{2}{|c|}{ Dollarization } & \multicolumn{2}{|c|}{ Joining EMU } \\
\hline & \$ Zone & $€$ Zone & & On Trade & On GDP & On Trade & On GDP \\
\hline Albania & 3 & 75 & 47 & 3 & 1 & 70 & 23 \\
\hline Belize & 44 & 8 & 103 & 90 & 30 & 16 & 5 \\
\hline Brazil & 23 & 24 & 15 & 7 & 2 & 7 & 2 \\
\hline Canada & 76 & 5 & 73 & 111 & 36 & 8 & 3 \\
\hline Chile & 21 & 17 & 55 & 24 & 8 & 19 & 6 \\
\hline Costa Rica & 53 & 17 & 86 & 91 & 30 & 30 & 10 \\
\hline Cote d'Ivoire & 7 & 73 & 77 & 11 & 4 & 112 & 37 \\
\hline Denmark & 4 & 49 & 64 & 6 & 2 & 63 & 21 \\
\hline Ecuador & 45 & 16 & 58 & 53 & 17 & 19 & 6 \\
\hline Egypt Arab Rep. & 18 & 38 & 53 & 19 & 6 & 41 & 13 \\
\hline El Salvador & 50 & 14 & 59 & 59 & 19 & 16 & 5 \\
\hline Fiji & 10 & 4 & 115 & 22 & 7 & 9 & 3 \\
\hline Guatemala & 44 & 10 & 45 & 39 & 13 & 9 & 3 \\
\hline Honduras & 52 & 17 & 91 & 95 & 31 & 31 & 10 \\
\hline Hungary & 4 & 71 & 76 & 6 & 2 & 107 & 35 \\
\hline Israel & 25 & 38 & 69 & 34 & 11 & 52 & 17 \\
\hline Korea & 22 & 11 & 67 & 30 & 10 & 14 & 5 \\
\hline Kuwait & 19 & 24 & 104 & 39 & 13 & 51 & 17 \\
\hline Mexico & 79 & 6 & 59 & 93 & 31 & 7 & 2 \\
\hline New Zealand & 13 & 11 & 59 & 16 & 5 & 13 & 4 \\
\hline Nigeria & 35 & 34 & 30 & 21 & 7 & 21 & 7 \\
\hline Norway & 6 & 43 & 70 & 9 & 3 & 61 & 20 \\
\hline Philippines & 24 & 10 & 81 & 39 & 13 & 16 & 5 \\
\hline Poland & 3 & 60 & 50 & 3 & 1 & 61 & 20 \\
\hline Singapore & 16 & 10 & 356 & 114 & 38 & 71 & 24 \\
\hline South Africa & 10 & 29 & 50 & 10 & 3 & 29 & 10 \\
\hline St. Kitts and Nevis & 21 & 2 & 123 & 51 & 17 & 6 & 2 \\
\hline Sweden & 8 & 48 & 76 & 12 & 4 & 72 & 24 \\
\hline Switzerland & 8 & 61 & 66 & 11 & 3 & 81 & 27 \\
\hline Thailand & 14 & 13 & 90 & 25 & 8 & 23 & 8 \\
\hline Turkey & 9 & 46 & 44 & 8 & 3 & 41 & 13 \\
\hline United Kingdom & 12 & 53 & 58 & 13 & 4 & 62 & 20 \\
\hline Zimbabwe & 4 & 21 & 91 & 8 & 3 & 38 & 13 \\
\hline Average (whole sample) & 4 & 48 & 69 & 5 & 2 & 54 & 18 \\
\hline
\end{tabular}

Notes

1: Currency Union predicted to triple trade.

2: Each percentage point in trade/GDP predicted to increase real GDP per capita by $.33 \%$.

3: The set of countries reported here are some for which the currency decision is of particular interest. For the full set of countries, see Table 4 in the working paper. 
[Appendix table]

TABLE A I

Currency Unions in the Bilateral Trade Data Set

\author{
Australia \\ Kiribati \\ CFA \\ Nauru \\ Benin \\ Tuvalu \\ Burkina Faso \\ Cameroon \\ Denmark \\ Central African Republic \\ Faroe Islands (part of Denmark) \\ Chad \\ Comoros \\ Greenland (part of Denmark) \\ ECCA \\ Anguilla (territory of UK) \\ (Republic of) Congo \\ Cote d'Ivoire \\ Gabon \\ Antigua and Barbuda \\ Dominica \\ Guinea-Bissau \\ Grenada \\ Montserrat (territory of UK) \\ Mali (post '84) \\ Niger \\ Senegal \\ St. Kitts and Nevis \\ St. Lucia \\ St. Vincent and the Grenadines \\ Togo \\ UK \\ Falkland Islands (territory) \\ Gibraltar (territory) \\ France \\ French Guiana (overseas department) \\ Saint Helena (territory) \\ Ireland (pre '79) \\ French Polynesia (overseas territory) \\ Guadeloupe (OD) \\ Martinique (OD) \\ Mayotte (territorial collectivity) \\ USA \\ US Virgin Islands (territory) \\ British Virgin Islands (territory of UK) \\ New Caledonia (OT) \\ Reunion (OD) \\ Saint Pierre and Miquelon (TC) \\ Turks \& Caicos Isl. (territory of UK) \\ Bahamas \\ Bermuda (colony of UK) \\ Liberia \\ New Zealand \\ Panama \\ Cook Islands (self-governing) \\ Niue (self-governing)

\section{Currency Boards in the Bilateral Trade Data Set} \\ UK \\ Bahrain (pre '74) \\ Fiji (pre '76) \\ Gambia (pre '72) \\ Oman (pre '75) \\ Qatar (pre '74) \\ Yemen (pre '72) \\ US \\ Argentina (post '90) \\ Cayman Islands (post '71) \\ Djibouti \\ Hong Kong (pre '75, post '82)
}




\section{Endnotes}

1 Lower inflation may in turn, promote higher growth through a variety of channels, including especially the development of capital markets; Barro [1991].

2 In the interest of brevity, below we sometimes shorten "currency unions or boards" to "common currencies" or "currency unions."

3 A survey of the literature is available in Edison and Melvin [1990].

4 Frankel and Wei [1995].

5 Our focus is on the currency union effect, in part because there were so few currency board arrangements during the bilateral trade sample. In 1990, only the Cayman Islands, Djibouti and Hong Kong used currency boards.

6 Anderson and van Wincoop [2001] provide a critique.

7 We can reproduce McCallum's estimate in our data set by dropping from the gravity equation all variables that tend to go with nationhood -- currency, language, trade policy -- leaving only the political union variable. When we do so, the home bias effect is estimated at McCallum's level of twenty. (The estimated coefficient on political union is 3 , and $\exp (3.0)=20$.)

8 E.g., Grossman and Helpman [1991a, 1991b], Helpman [1988], and Helpman and Krugman [1985].

9 Among the many examples are: Romer [1989], Dollar [1992], and Edwards [1993a]. Edwards [1993b] and Rodrik [1993] survey the literature.

10 For example, Edwards [1993a, pp.9-11] regresses the rate of growth of total factor productivity on two measures of openness (total trade as a percent of GDP, and total tariff revenue as a percentage of trade) along with some other variables, and finds that "in every regression the proxies for trade distortions and openness are highly significant." 11 E.g., Fischer [1991, 1993], Dollar [1992], Easterly [1993], Edwards [1993], Sachs and Warner [1995] and Harrison [1996]. Rodriguez and Rodrik [2000] offer a critique of much of this work and conclude that the issue remains unsettled.

12 From the viewpoint of a small individual country, the GDPs of its trading partners are exogenous as well. For a study like this that seeks to explain output for a cross-section of countries, one does not wish to treat the output of trading partners as exogenous, even if the domestic country is small.

13 Frankel and Romer use samples ranging from 98 to 150 countries and find that the coefficient on openness in an output equation goes from 0.8 in an OLS regression to over 2.0 with instrumental variable estimates. The estimated openness coefficients are lower when conditioning on initial income and factor variables -- 0.34 when using the gravity instrument (Frankel, Romer and Cyrus, 1996). They remain statistically significant in either case.

14 Barro [1991], Barro and Sala-i-Martin [1992], and Mankiw, Romer, and Weil [1992].

15 Since we only generate and use a single instrument, we have no over-identifying restrictions to test.

Nevertheless, we can "disaggregate" our instrument into its underlying gravity components. The first stage, which we use to generate our instrument, comprises six underlying variables: distance, population, common language dummy, common land border, area, and landlocked status. We also used each of these, one by one, to generate an instrument from a single gravity determinant, resulting in six "generated instruments". Then we conducted our exclusion tests by excluding from the income equation (and testing the significance of) the difference between this generated instrument and our baseline instrument of Table II; this variable measures the independent contribution from the gravity determinant. We then use the other five generated instruments to instrument for openness. Using this methodology delivers twelve exclusion tests: two for each of the six gravity determinants, depending on whether we include or exclude controls from the income equation. With the exception of population in the version without controls, the t-statistics are insignificantly different from zero at conventional significance levels, suggesting that the contribution of the gravity determinants to the instrument can in fact be excluded from the output equation. To summarize succinctly, the implicit over-identifying restrictions do not seem grossly violated. (We thank an anonymous referee for this suggestion.)

16 This estimate happens to be close to the gravity-IV estimate (.34) of Frankel, Romer and Cyrus [1996; table 2]. 17 When we include both actual and gravity-predicted trade in our output equation, we find no evidence inconsistent with the hypothesis that policy-induced openness has a positive effect on income similar to that of gravity-predicted openness. Details are available upon request.

18 The coefficients on the factor accumulation variables are reported, not here, but in the NBER working paper version.

19 Institutional quality is measured by scores for: a) corruption, b) law and order, and c) bureaucracy for 1990 taken from International Country Risk Guide (which Rodrik kindly gave us). The three different measures are scaled from 
1 (worst) through 6 (best). We have also followed Rodrik in employing a rescaled unweighted average of the three measures.

${ }^{20}$ An exception is Alesina and Barro [2000], who provide an elegant model that incorporates the trade effect. 21 Ghosh, Gulde and Wolf [2000] find that currency board countries on average have higher growth than other countries: a difference of 1.8 percent per annum, whether in an equation that conditions on such other variables as initial income, investment, and human capital, or in unconditional averages.

22 Adding inflation instead of the currency union/board variable leads to similar conclusions.

${ }^{23}$ Levy-Yeyati and Sturzenegger (2001) find that countries that follow de facto fixed exchange rates have lower growth rates than floaters, and discuss theoretical reasons why this might be.

24 More exactly, we use the average of this variable between 1970 and 1990.

25 We note in passing that our framework does not rule out the idea that other economic interactions along geographic lines, such as investment, communication, and movement of people, could constitute part of the growth effect, rather than exclusively trade.

26 Historical evidence regarding the formation and dissolution of federations might offer a clue regarding lags. Within five years of the re-unification of East and West Germany in 1989, intra-German trade concentration increased four-fold. Similarly, after the break-ups of the Austro-Hungarian Empire, the Federation of Malaya, the Soviet Union, and Czechoslovakia, trade patterns among the constituent parts in each case shifted away from one another within a few years (Frankel, 1997). In each case, the introduction of different currencies may explain part of the effect, though it is conflated by other events. In each case the impact after five years seems to have been far less than a full home bias effect.

27 Persson uses non-parametric matching techniques on the data set of Rose (2000) and finds that the effect of currency union on trade is smaller than the tripling estimate, and that it is less precisely estimated, though still positive and usually significant. The response, Rose (2001), exploits a larger data set to try to address the possible endogeneity of the decision to leave or join a currency union (using linear, matching and panel fixed-effect techniques) and once again finds that the effect on trade is large, positive and significant. 